\title{
Alternative Comparison of Government Strategies of ASEAN Countries in Addressing Public Welfare Problems During Covid-19
}

\author{
Ravire Kethryn ${ }^{1}$, Bianca Salonga ${ }^{1}$ \\ ${ }^{1}$ Student of Department of Social Sciences and Philosophy, Univesity of Northtern of \\ Philippiness, Philippiness \\ Received: March 15, 2021 \\ Received in Revised: April 10, 2021 \\ Accepted: April 21, 2021
}

\begin{abstract}
Cooperation takes place through ASEAN, ASEAN + 3, and other processes, as well as through cooperation with other organizations. The numerous partnerships address a variety of issues, including prevention in the health sector, economic responses, and tourism and travel interventions. Another growth approach pursued by ASEAN is trade policy. To mitigate the pandemic's effect on inter-country exchange, the ASEAN countries' primary objective is to preserve and restore trade ties by holding markets free. ASEAN interventions in response to the economic effects of the Covid-19 pandemic have been outlined in three categories: economic stimulation, monetary and fiscal policies, and exchange policies, both of which aim to maximize social welfare during the tough periods of the Covid-19 pandemic.
\end{abstract}

Keywords: Policy, Cooperation \& Community Welfare

\section{Introduction}

After the Covid-19 pandemic began in early January 2020, no ASEAN member nation has been immune to the corona virus. According to WHO data as of August 3, 2020, Indonesia had the highest number of Covid-19 cases in the ASEAN zone, with 111,455 cases. The Philippines reported 103,185 cases, Singapore reported 52,825 cases, Malaysia reported 8,999 cases, Thailand reported 3,320 cases, Vietnam reported 621 cases, Myanmar reported 353 cases, Cambodia reported 240 cases, Brunei Darussalam reported 141 cases, and Laos reported 20 cases. Faced with these circumstances, ASEAN, as a regional body that facilitates state collaboration in Southeast Asia, collaborates to mitigate the corona virus's negative impact. Cooperation takes place through ASEAN, ASEAN + 3, and other processes, as well as through cooperation with other organisations. The numerous partnerships address a variety of issues, including prevention in the health sector, economic responses, and tourism and travel interventions. Progress has been made as a result of the ASEAN health sector's initiatives, which include exchanging knowledge and experiences in dealing with Covid-19, including with ASEAN speech partners through the ASEAN Emergency Operations Center (EOC) Network webinar portal, and educating one another in real time through short messages about cross-border travel. Limits on suspect / patient validation states; periodic monitoring of the ASEAN BioDiaspora Virtual Center's Risk Assessment for International Dissemination of Covid-19 ASEAN Region; risk coordination activities through the ASEAN Risk Assessment and Risk Communication Center; and funding for laboratory capability strengthening.

\section{The efforts of the governments of the Asean countries in overcoming problems of people's} welfare

\section{Security of health}

After the outbreak of the Covid-19 pandemic, the ASEAN health sector has triggered a variety of regional health collaboration systems to address the pandemic. There are currently at least 
twenty-seven ASEAN systems in place or being implemented to cope with Covid-19. The ASEAN Emergency Operation Center Network for Public Health Emergencies (ASEAN EOC Network), hosted by Malaysia, provides regular updates on the situation and technological developments surrounding Covid-19 to each ASEAN member. The ASEAN EOC Network also updates the ASEAN website with the new changes in the Covid-19 situation in ASEAN. The ASEAN BioDiaspora Virtual Center, which is headquartered in the Philippines, utilizes Big Data to generate risk assessments and surveillance reports for Covid-19. Subsequent reports will be published three days a week. The Regional Public Health Laboratories Network (RPHL), which is led by Thailand, provides each ASEAN member with laboratory preparation, technological and material support, as well as laboratory expertise and supervision. The ASEAN Risk Assessment and Risk Communication Center (ARARC) stresses the critical nature of risk communication in responding to public health emergencies. ARARC undertook an inquiry into false news and hoaxes around Covid-19 and identified appropriate methods for reaching out to the public and providing reliable and timely facts. Additionally, there are several implementation strategies for a number of new initiatives, including the establishment of the ASEAN Plus Three Pharmaceutical Industries Network, the development of the ASEAN health protocol in light of the New Normal era, the development of a cross-border contact tracing and rapid outbreak investigation protocol, and the establishment of the ASEAN Plus Three Task Force on.

New initiatives have been agreed upon and are currently being developed. They include the establishment of an information platform for the public ASEAN Portal for Public Health Emergency; the establishment of the ASEAN Center for Public Health Emergencies and Emerging Diseases; the development of a multisectoral ASEAN Public Health Emergency Coordination System (APHECS); and the development of the ASEAN Comprehensive Recovery Framework. The multiple initiatives outlined above resulted from a series of ASEAN meetings to collaborate and share ideas about how to manage Covid-19 in the health sector, which included welcoming many negotiation partners, including the United States of America, China, Australia, and the European Union. One of them was a video conference meeting between the ASEAN and US Ministers of Health on April 30, 2020. Ministers of Health from ASEAN member countries and the United States, as well as the ASEAN Secretary General, attended the conference. The objective is to strengthen ASEAN-US health cooperation in the fight against Covid-19.

\section{Economic policy}

ASEAN countries have reacted to the effects of the Covid-19 pandemic with a variety of economic policies. ASEAN's strategies in response to the economic effects of the Covid-19 pandemic have been classified into three categories: economic stimulus, monetary and fiscal policy, and trade policy (bin Ridzuan \& Abd Rahman, 2021; Hutchison, 2020; Alozie et al., 2020; Djalante et al., 2020). The ASEAN Policy Brief 1 summarizes the ASEAN countries' strategies in introducing different economic stimulus packages. To offset the economic effects of Covid-19, ASEAN member states have unveiled a series of economic stimulus packages since February 2020. In general, countries' policies ASEAN countries fall into five categories. The first category is tax breaks for impacted companies. Second, grants ranging from monetary aid to concessions on utility bills to extra benefits for those employed in the health sector; third, delayed tax or loan payments; fourth, fee refunds or reduced government fees; and fifth, the Central Bank pursues a programme of interest rate reduction and purchases of shares / government bonds. 


\section{Asean government policies in improving people's welfare}

Additionally, many ASEAN countries have adopted special policies. Numerous countries concentrate their efforts on the major sectors of society. Brunei permits the cessation of pension payments, while Malaysia permits reductions. Singapore, on the other side, has suspended loans and school fees (student loan and charges). Additionally, Vietnam's banking sector established a credit package worth 12.3 billion US dollars for commercial activities. International financial organizations have also lent assistance to countries hit by the Covid-19 pandemic. The IMF pledged to boost member countries' lending potential to a trillion dollars. Additionally, the IMF committed to reducing debt for low-income countries through the Catastrophe Containment and Relief Trust (CCRT) scheme. Additionally, the World Bank issued funds totaling 160 billion US dollars over the next 15 months for long-term funding.

The Philippines and Indonesia are two ASEAN countries that have won grant approval from the ADB. The Philippines initiated a five-million-dollar Rapid Emergency Supplies Provision Project to offer temporary nutritional aid to Luzon's most needy households and staff. Meanwhile, Indonesia used a US \$ 3 million fund to acquire critical medical facilities and services, including ventilators and personal protective equipment. ASEAN Policy Brief 1 also makes six policy recommendations to ASEAN member countries, including the following: using all available macroeconomic, financial, and structural policy tools; maintaining productive economic capacity; maintaining supply chains; leveraging technology and digital commerce; strengthening safety nets; increasing regional response to pandemics; and the determination to

\section{Fiscal and Monetary Policy}

Numerous monetary and fiscal policy plans for ASEAN member countries are being affected by the economic effects of Covid-19. The aviation, wellness, and agriculture industries are the three main sectors targeted by monetary and fiscal policies. Monetary policy is one of the first tools used to guarantee the availability of liquidity and boost economic stability in times of supply chain disruptions and trip cancellations (Ihle et al., 2020; Popoyan et al., 2017; Loayza \& Pennings, 2020; Chetty et al., 2020). After the outbreak of the pandemic, central banks in ASEAN countries have adopted policies to slash interest rates, decrease reserve levels, and buy reserves in order to preserve financial stability, ensure system liquidity, and reduce credit costs. These monetary interventions are also meant to demonstrate to the public that the government is able to go to whatever length to guide the country out of the recession and preserve the banking sector's stability. Numerous ASEAN countries allow the banking industry to promote credit without jeopardizing the health of banks. The Central Bank of Vietnam is advising commercial lenders to cut payment costs by at least $50 \%$ using electronic interbank structures and to restrict dividends and running costs in order to retain an adequate capital stock. In the other side, the Lao Central Bank released recommendations urging lenders to restructure the borrowing of impacted debtors, including a one-year grace period and interest rate reductions. These initiatives aim to boost liquidity and investor trust while still ensuring the stability of the monetary and financial systems. Apart from internal cooperation, ASEAN is in talks with allies over collaborating to combat the Covid-19 pandemic. In terms of financial collaboration, ASEAN +3 also collaborated to reinforce the Chiang Mai Initiative Multilateralization (CMIM), a multi-currency exchange regulatory framework that enables participants to access short-term liquidity in times of need. As the pandemic's influence expands, ASEAN governments are increasing fiscal support to boost health sector capability and offset the wider economic effect of the hardest-hit industries, such as tourism and MSMEs. Fiscal initiatives by ASEAN members fall into three groups. To begin, let us consider household subsidies. Second, 
tax and fee exemptions or moratoriums, even leasing payments. The third is a freeze or debt restructuring for companies and people impacted by the pandemic.

In the fiscal market, ASEAN countries are implementing fiscal packages totaling US \$ 318.2 billion, or 10.1 percent of ASEAN GDP in 2019. Thailand has the biggest stimulus program, totaling US $\$ 88.8$ billion. Underneath that is Indonesia, which has 81.8 billion US dollars, of which 43 billion US dollars have been accepted for economic stimulus packages. Apart from the sectors worst hit, the stimulus included funds for the insurance industry and family subsidies.

Another ASEAN approach in the economic sector is trade policy. To mitigate the pandemic's effect on inter-country exchange, the ASEAN countries' primary objective is to preserve and restore trade ties by holding markets free.

At least four years, ASEAN countries have collaborated to hold the sector accessible. To begin, on March 10, 2020, the ASEAN economic ministers released a joint statement on improving ASEAN's economic resilience in response to the Covid-19 pandemic. This demonstrates ASEAN's contribution to economic transparency and integration. On April 15, 2020, the ASEAN agriculture and forestry ministers released a joint statement. The statement reaffirmed the commitment to avoid disruptions to food supply chains in the ASEAN area, to maintain free markets, and to abstain from export controls, quotas, and restrictions, as well as tariff and non-tariff barriers.

ASEAN's leaders have committed to maintaining a free market for trade and investment and to enhancing cooperation with ASEAN members and with ASEAN partner countries. ASEAN Economic Ministers adopted the Hanoi Plan of Action to bolster ASEAN economic integration and supply chain connectivity in the aftermath of the Covid-19 pandemic. The agreement includes joint actions to facilitate the exchange in vital commodities (food, medications, surgical devices, and other relevant products), as well as to facilitate the manufacture and access to Covid-19 medicines and vaccines through improving supply chain connectivity. The Hanoi Plan of Action is expected to encourage ASEAN member countries to be more proactive in implementing concrete steps, such as the use of Affixed Signature and Stamp (ASnS) to ensure the smooth flow of trade in the face of social restriction policies, the optimization of the ASEAN Single Window as a platform for exchanging trade administration documents, and the increased use of digitalization. In addition to the numerous declarations outlined above, ASEAN is dedicated to ensuring market openness by advancing the trade agenda, specifically by phasing out tariffs and maintaining collaboration with non-ASEAN partners. Apart from intergovernmental coordination ( $\mathrm{G}$ to $\mathrm{G}$ ), the private sector also contributes to the economic sector's response to the pandemic. The ASEAN Business Advisory Council and its representatives are strongly recommending measures to ensure the continuous manufacturing and supply chains of fruit, drinks, and critical medical equipment.

According to Shepherd \& Wilson, (2009); Soesastro, (2007) Priority should be provided to trade reforms that ASEAN countries should implement. The first advice is to make a commitment to securing supply chain connections, especially for vital products. The second guideline is to pay close attention to the importance of commerce in economic growth after an outbreak. The third suggestion is to promote the adoption of a digital agenda that is effective in reacting to the pandemic's effects. Fourth, reiterating the importance of expanded multilateral collaboration. Finally, we advocate encouraging the private sector and other stakeholders to maintain supply chain stability, instill investor trust, and promote regional postpandemic recovery; and reviving multilateralism to ensure global competitiveness and sustainability post-Covid-19. Recovery in tourism and transport. 
Apart from commerce, the tourism and travel industries in ASEAN were hardest hit by the Covid-19 pandemic, owing to widespread travel bans across the country. Indeed, tourism and transport industries account for $12.6 \%$ of the ASEAN economy. Cambodia, the Philippines, and Thailand are the ASEAN countries that have felt the biggest effect of Covid-19 on the tourism market, owing to the significant contribution of tourism to GDP. Both ASEAN countries are feeling the effects of the Covid-19 pandemic in the aviation industry. Indonesia and Thailand are the most heavily impacted countries in this market. Due to flight constraints, the number of airplane passengers in Indonesia decreased by 59.8 million, although it decreased by 55.6 million in Thailand. This culminated in a loss of US $\$ 8.2$ billion in future sales in Indonesia and Thailand, respectively. At the regional stage, the ASEAN National Tourism Organization released a joint statement on 13 February 2020 to solicit information on preventive steps and the situation in each ASEAN member country. Singapore's national tax program favors the travel and aviation industries.

Facilitating ASEAN coordination in order to expedite the sharing of travel details, particularly regarding health standards and other measures necessary for ASEAN member countries to take in order to contain the spread of the COVID-19 outbreak, through increased operations of the ASEAN Tourism Crisis Communication Team (ATCCT). intensify cooperation between ASEAN National Tourism Organizations (NTOs) and other key ASEAN sectors, especially health, intelligence, transportation, and immigration, as well as with external ASEAN partners, in order to jointly implement robust, open, and sensitive initiatives. swiftly in managing and minimizing the effects of Covid-19 and future crises. The ministers also agreed to strengthen cooperation in exchanging knowledge and best practices in support of the tourism sector among ASEAN member countries and with ASEAN dialogue partners. Additionally, this collaboration entails the implementation of effective policies and initiatives aimed at fostering confidence among domestic and foreign visitors to Southeast Asia. This involves implementing criteria and recommendations for enhancing protection and health factors in the hotel and other tourism-related sectors in order to safeguard staff and the public. The tourism ministers have decided to endorse the establishment and execution of a post-Covid-19 crisis recovery strategy, as well as the development of ASEAN tourism capability and joint tourism promotion and marketing activities aimed at advancing ASEAN as a single tourism destination. The ministers agreed to accelerate the introduction of micro and macroeconomic policies, to provide technical assistance and financial stimulus, to reduce taxes, to develop capability and capabilities, especially in the area of digital skills, for stakeholders in the travel and tourism industry. intensify collaboration with ASEAN speech partners, international organizations, and related industries in order to create a resilient Southeast Asia capable of implementing and managing healthy and inclusive tourism successfully following the crisis.

\section{Conclusion}

Numerous monetary and fiscal policy plans for ASEAN member countries are being affected by the economic effects of Covid-19. The aviation, wellness, and agriculture industries are the three main sectors targeted by monetary and fiscal policies. Monetary policy is one of the first tools used to guarantee the availability of liquidity and boost economic stability in times of supply chain disruptions and trip cancellations. Comprehensive, open, and rapid response mechanisms are essential for mitigating and minimizing the effects of Covid-19 and subsequent crises. Several initiatives to promote communal wellbeing include the following: Strengthening the community's social and cultural resilience focused on the noble ideals of indigenous culture. Increased neighborhood inventiveness of using natural capital. To foster a clean, tidy, lawabiding, and harmonious community existence. Developing a policy to cultivate a village of citizens who value fitness, nutrition, safe habits, and physical and spiritual cleanliness. 


\section{References}

Alozie, C. E., Ideh, A. O., \& Ifelunini, I. (2020). Coronavirus (COVID-19) Pandemic, Economic Consequences and Strategies for Ameliorting Macroeconomic Shocks in Nigeria's Economy. Economic Consequences and Strategies for Ameliorting Macroeconomic Shocks in Nigeria's Economy (September 21, 2020).

bin Ridzuan, M. R., \& Abd Rahman, N. A. S. (2021). The Deployment of Fiscal Policy In Five ASEAN Countries in Dampening The Impact of COVID-19. Journal of Emerging Economies \& Islamic Research, 9(1).

Chetty, R., Friedman, J. N., Hendren, N., \& Stepner, M. (2020). How did covid-19 and stabilization policies affect spending and employment? a new real-time economic tracker based on private sector data (No. w27431). National Bureau of Economic Research.

Djalante, R., Nurhidayah, L., Lassa, J., Minh, H. V., Mahendradhata, Y., Phuong, N. T. N., ... \& Sinapoy, M. S. (2020). The ASEAN's responses to COVID-19: A policy sciences analysis. Available at SSRN 3595012.

Hutchison, M. M. (2020). The Global Pandemic, Policy Space and Fiscal Rules to Achieve Stronger Stabilization Policies. Seoul Journal of Economics, 33(3).

Ihle, R., Rubin, O. D., Bar-Nahum, Z., \& Jongeneel, R. (2020). Imperfect food markets in times of crisis: economic consequences of supply chain disruptions and fragmentation for local market power and urban vulnerability. Food Security, 12(4), 727-734.

Loayza, N. V., \& Pennings, S. (2020). Macroeconomic policy in the time of COVID-19: A primer for developing countries.

Popoyan, L., Napoletano, M., \& Roventini, A. (2017). Taming macroeconomic instability: Monetary and macro-prudential policy interactions in an agent-based model. Journal of Economic Behavior \& Organization, 134, 117-140.

Shepherd, B., \& Wilson, J. S. (2009). Trade facilitation in ASEAN member countries: Measuring progress and assessing priorities. Journal of Asian Economics, 20(4), 367383.

Soesastro, H. (2007). Implementing the ASEAN economic community (AEC) blueprint. Soesastro, H. eds, 1-2. 